\title{
Changing Political Trends in Khyber Pakhtunkhwa: A Case Study of Malakand (1968-
}

\author{
2013) \\ * Junaid Babar, Lecturer \\ ** Aabida Lateef, PhD Scholar \\ *** Nasrullah Khan (Corresponding Author)
}

\begin{abstract}
This paper delineates political and cultural shifts in the Malakand district of Khyber Pakhtunkhwa $(K P)$, Pakistan. The paper challenges dominant perceptions and discourses about the people of KP in the post $9 / 11$ context and presents an alternative version of history and politics. It traces the history of peasant movements and indigenous resistance (1968-1977) for gaining social, economic, and political equality. It is argued that state policies, the influence of regional and global powers have brought radical changes in the whole province in general and in Malakand in particular. In addition to the role of state's ruling elites and international agencies, the emphasis is on changing demographic and economic conditions which favored religious right at a deep societal level. Qualitative method has been adopted while conducting this research work which involves extensive fieldwork in the Malakand district. Archival and vernacular sources have also been consulted for tracing the history of progressive politics in the province.
\end{abstract}

Keywords: Religious Right, Political Change, Progressivism, State, Society.

\section{Introduction}

Contrary to the dominance of right-wing politics in Pakistan from the last three decades, the politics of the late 1960s' and early 1970s' was progressive in many aspects. Left political movements and discourses were dominant in different parts of the world in the second half of the 20th century and influenced countries worldwide, including Pakistan. Not only on the political front, progressive ideas had widely circulated and dominated the cultural front too in Pakistan. Left-wing political parties, unions, and activists were active in both urban and rural areas: In urban centers, trade and left-wing student unions were active, while in rural areas, land was the center of political contestation between the landless classes and the landed elites (Ali, 2011).

In the late 1960s' and 1970s', peasant movements were at its peak in different parts of the country, especially in the then North West Frontier Province (NWFP), including the violent conflicts in the lands of Hashtnagar and Malakand. Such movements were inspired by Maoists revolutionary tactics - based on getting liberated zones free from the influence of imperialism and local landlords. Also, left forces were dominant in the cultural sphere. The cultural expressions existed in the form of progressive magazines, papers, dramas, poetry, prose, etc.

However, in the last few decades, radical shifts have been taken place towards the right in the region as a whole and Pakistan in particular. There are several reasons and factors-both domestic and international - that have brought such radical shifts. It is important to delineate that how the religious right, which was once conspicuous by its absence among the subordinated classes in the late 1960s' and 1970s', has been strengthened and expanded deeply into the wider societal level in the last few decades.

\section{Literature Review}

Like many other states, history in Pakistan is written both from the 'official' as well as from the 'unofficial' perspectives. This paper relies on the 'unofficial' version of literature in tracing Pakistan's political history. Toor's (2011) book "The state of Islam: Culture and Cold War politics in Pakistan" is a rich contribution in tracing the history of the left and the state's support to right-wing forces in Pakistan in the Cold War period. She argues that, since the inception of the country, political left

\footnotetext{
* University of the Poonch, Rawalakot

** Arid University, Rawalpindi

*** University of the Poonch, Rawalakot AJK Email: nasrullahafd123@gmail.com
} 
presented a strong alternative to resolve the identity crises of the newly born state. The Communist Party of Pakistan (CPP) and Progressive Writers Association (PWA) presented an alternative view of nationalism, but rejected not only by the state elites but also by the liberal intellectuals. Also, a detail of intellectual debates between the leftist intellectuals - who were mostly associated with the PWAand the liberal intellectuals - who were supporting the 'official' version of nationalism - has been discussed in the book. There is, however, limitation in mentioning the ethno-nationalists' version of nationalism -as discussed in detail by Ahmed (1979) in his book "Ethnicity and Politics in Pakistan". This work is also worthy to understand Pakistan's alignment in the US block, and the latter's interest in containing communism in this part of the world by supporting right-wing forces and ideologies. According to her, left was systematically undermined from the mainstream, as the marginalization of the progressive forces was essential for the 'Islamization' of state and society in the Zia regime. The main reason behind patronizing the religious right by the ruling elites and the US in the Cold War period was to undermine progressive politics. Furthermore, the resistance of women from the platform of Women Action Forum (WAF) against the repressive and misogynist policies of General Zia has also been discussed in the book. Apart from the left politics of the late 1960s' and 1970s', the book discusses the nature of 'progressive' politics in the late 1980s and 1990s. According to the author, NGO's culture has replaced the old 'militant' politics of the left. After the retreat of the Left with the defeat of the USSR, the alternative to the hegemony of the state and the religious right was championed by liberals in the form of NGO's. Despite successfully raising some individual cases, NGO's, however, proved a weak alternative to counter the hegemony of the ruling elites and the retrogressive religious right.

Notwithstanding her sincere attempt to address the rise and fall of left-wing politics in the Cold War period in Pakistan, many loopholes need to be filled. For instance, she did not discuss progressive political movements in the smaller provinces, or those areas lie outside the mainland Punjab. There is no detail of peasant uprisings in different parts of the country in the 1970s'. Lastly, there is no detail on the rise of right-wing forces and their expansion into those subordinated classes in the last few years which were once represented by the left.

Akhtar's (2018) book "The politics of common sense in Pakistan" has been built on the seminal work of political scientist and sociologist Alavi (1972). Not only he filled the gaps within the work of Alavi, but he also discussed the emergence of two 'new' groups into the established oligarchic order of the ruling elites which were dominated by bureaucracy, military, and the propertied classes since the inception of the country. The writer argues that in the last few decades 'military dominates the oligarchic order and has endangered its historical relationship' with other partners in the 'historical bloc'. During General Zia's era, two major changes have taken place; first, the emergence of the 'intermediary' classes and their co-option to the old 'historical bloc': The inclusion of the subordinate classes into the lower bureaucracy has further expanded the co-option process. The second addition to the ruling coalition is the inclusion of religious rights: The religious right has become an important part of the oligarchic order with the arrival of General Zia. 'Islam' had not been only instrumentalized by Gen Zia for maintaining his legitimacy but also to diffuse the politics of resistance. The expansion of Zia's interpretation of religion into the wider social formation has diffused resistance of subordinate clauses. Besides the inclusion of the religious right, lower bureaucracy and increasing urbanization have also played a role in strengthening the established order of the ruling elites. The writer argues that the hegemonic order of the ruling elites has been accepted even by the subordinate classes who are at the margin of the existing system as a "common sense". The politics of resistance has been replaced by the politics of "common sense". A counter-hegemonic project against the hegemony of the ruling elites is also been discussed by the writer. He argues that, within the oligarchic order of the ruling elites, it is not possible to co-opt all the subordinate clauses. When objective and subjective conditions conspire, the subordinate classes have then the capacity to challenge the hegemonic order of the ruling elites.

Ali (2015) in his book "Surkh Salam: Communist Politics and Class Activism in Pakistan 1947-1972" discusses the history of CPP, PWA, labor and trade unions during the Cold War period in Pakistan. He traces the history of communists who had migrated to Pakistan for building a communist movement: Famous among them were the Secretory General, Sajjad Zaheer, left-wing author Sibt-iHassan and Ashfaq Beg. The selfless sacrifice of Hasan Nasir for the downtrodden and oppressed people of the country - to whom he was an 'immigrant' - is discussed in great detail by the author. 
Also, the writer discusses the cultural debates between the left and liberal intellectuals in the postPartition period in Pakistan. However, like Toor (2011), the history of left-wing political movements in the smaller provinces is not being included in his book. His work also falls short to trace the proper history of peasant movements in rural areas of the country. For instance, there is a lot of detail in his book about labor politics in urban centers such as Karachi, but there is no detail of peasants uprising in places like Hashtnagar in the Cold War period in Pakistan. Also, the era in his books and papers remains mostly confined to the left-wing politics in pre-Zia Pakistan that is why the shift towards the right at state and societal level is not a part of his work.

Ph.D. dissertation of Leghari (1979), titled, "The Socialist Movement in Pakistan: An Historical Survey, $1944-74$ " is an important source that traces the history of left-wing political parties and socialist movements in Pakistan. His extensive fieldwork in the era when the left was a living reality is helpful to understand left-wing political movements and politics in Pakistan. He argues that, before the partition, the communists in those areas which later became Pakistan were dominated by the Sikhs of Punjab, who migrated to India on the eve of partition violence and thus left a vacuum. That is why the CPP was made in India in February, 1948, and led by the Urdu speaking folks such as Sajjad Zaheer and Sibt-i- Hasan. Despite being sincere with the socialist/communist cause, the lack of experience and the exclusive policies of the state elites - under the patronage of the US - didn't allow the leaders of CPP to make a coherent political party or built a revolutionary political movement. Communists, though, made different experiments for survival such as involvement in "frontal" politics, etc. Labour, trade, and student unions were active in different cities of the country. He is among those exceptional writers who wrote on the peasant uprisings that took place in different parts of the country as a result of Ayub Khan's industrialization policy. According to Leghari, the objective conditions for a socialist revolution were favorable in the late 1960s' but manipulated by Zulfiqar Ali Bhutto on his populist rhetoric. It was mainly due to the absence of a united left-wing political party. The formation of the National Awami Party (NAP), various splits within the NAP, and differences between the ethno-nationalists and communists are being discussed in his work. Not a single political party succeeded to bridge the gap between the urban and the rural political parties of the left in the late 1960s and 1970s. Despite the extensive fieldwork being conducted by the writer, there are still many vacant spaces in tracing various dynamics of the left history and politics in Pakistan. Unfortunately, so far, no other major work has been done to cover other important aspects of the left-wing political parties and movements in Pakistan. Also, there is no major work done on the retreat of the left in the post-Bhutto period. Leghari's era is also restricted to the pre-Zia era that is why the rise and expansion of the religious right are not a part of his work.

Room's (2013) book "The North-West Frontier (Khyber Pakhtunkhwa): Essays on History" is helpful to understand the broader political history of the KP and Malakand Division. He writes in detail about the history of the Malakand Division and the experience of the people with the colonial as well as the post-colonial state. The role of the state is important to trace the rise of religiopolitical movements in places like Swat and Malakand. The Constitutional Reforms of the late 1960s and its impacts on the politics of the area are an important aspect of his work. According to the writer, the religiopolitical movements of Sufi Muhammad and Fazlullah had a connection with the delaying process in the incumbent judicial system implemented after the merger of Swat state in Pakistan. On the gender question, the writer argues that it's not only religion but the nexus of tradition and religion in the patriarchal system that is depriving women of their due rights, especially from the right to own property.

Anthropological works have been done in places such as Swat. Barth (1959) and Lindholm (1982) made the pioneer contribution to understanding the cultural anthropology of Pakhtun society. Notwithstanding providing sufficient understanding of the social formation, power structure, and culture dynamics of the places, there are still many loopholes in the work done by foreign anthropologists. For instance, Asad (1972) in his critique addressed shortcomings in Barth's version of Swat's social formation and argued that the writer missed the question of class in his analysis. Jan's (2010) Ph.D. dissertation titled "Contested and Contextual Identities: Ethnicity, Religion, and Identity among the Pakhtuns of Malakand, Pakistan" is more relevant. It is a marvelous effort to understand the cultural anthropology of Pakhtun society from a researcher who is not only well versed in the vernacular but has also grown up in that society. The author argues that within Pakhtun society various identities are being contextual and contested. That is why the writer discusses society from the 
perspective of class, ethnicity, religion, and the state. Various identities based on class (landed and landless, local and immigrants), ethnicity (Pukhtunness, Islam, and 'Pakistani') are contextual and contested among Pakhtun in their everyday lives. As the writer conducted fieldwork in Malakand, that's why it contains useful information regarding the district's history, social formation, politics, and the role of religion. He discusses the indigenous struggle of the' immigrants' in Batkhela for gaining social and political equality. It is noteworthy that the struggle started at a time when left politics was at its peak at international as well as at the national level. Secondly, he discusses the peasants' struggle in these two towns against the landed elites of the area. The changing equation of classbrought out by migration and urbanization-is discussed in detail by the writer. The growing religiosity in the areas and the people's shifting identities to "Muslimness" in the last few years is also noteworthy in the context of this paper. His study is, however, cultural anthropological, and has limitations to explain complex political dynamics at the national and international level. Also, his fieldwork is based on the two towns of Batkhela tehsil and doesn't discuss other parts of the district. Like Room (2013), he views the movement of Sufi Muhammad in the 1990s as a response of people to the failure of the incumbent judicial system. There is no detail of the state's policies since Gen Zia time. Similarly, he doesn't discuss that how those subordinate classes associated with progressive politics in the late 1960s' and 1970s' engaged with the religiopolitical movements of Sufi Muhammad and Fazlullah.

Nasr (1994) in his book “The Vanguard of Islamic revolution: The Juma'at-i- Islaami of Pakistan" discusses in detail history, organizational structure, social bases, changing tactics, and political ambitions of Jumaat Islami (JI), Pakistan. He discusses the stance of JI's ideologue and leader, Maulana Maududi at the time of partition of India, and his writings on the politics of Congress and the Muslim League. He sheds light on the relation of Maulana Maududi with the Muslim League leadership and also the former's political ambitions while coming to Pakistan at the eve of Partition. According to Nasr, the ideological commitment of 'the Jamaat was to win over the hearts of the educated class' of the newly born country: In short, the Party wanted to bring the Islamic revolution from above. The Jama'at started working among the educated immigrants from India and made it its strong social base. The changing political conditions and the failure of their initial formula - of bringing revolution from above - compelled them to reconsider their original ideology. The Party's commitment to its ideology and its reluctance to address the genuine socio-economic issues remained the main theme of the book. He further argues that a gap existed between the Jamaat's ideological commitment and support of subordinate classes based on it. Moreover, his work gives us a broader understanding that how ideological politics without proper social bases are insufficient to bring revolution or fundamental changes in the state structure. The writer also discusses how JI and its student body, the IJT, were involved in the 'anti-left' politics in Pakistan. JI not only remained loyal to the ruling elites in every crisis but also remained their strong ally against ethno-nationalists and leftists. However, he doesn't discuss the role of the Jamaat in jumping into the social bases which were once occupied by the left. Also, he doesn't discuss the relationship of the Jama'at with the US and Arab countries developed in the Cold War period. As Nasr's area of interest is limited to Jama'at Islami that's why it doesn't include other religiopolitical groups who changed their ideological commitments for gaining popular support of the masses.

An important research paper that is primarily based on the work of Nasr is written by Iqtidar (2010) titled, "Jama'at Islami of Pakistan: Learning from the Left". In her paper, the writer discusses that the right-wing JI remained in opposition to the left-wing politics and strategies in the late 1960s' and 1970s' but, after the decline of the left, formed different unions on its pattern to capture those social spaces once occupied by the left. The party was, though, founded on an ideological basis and its social hub remained confined to the educated class, but with the changing political conditions and ground realities, Jamaat did adopt left-wing tactics into her politics. The party which initially opposed any radical reforms for the subordinate classes ironically jumped and tried to champion the cause of the peasants and workers. However, it is a limited study and doesn't discuss that up to what extent the broader religious right has established presence among the subordinated classes. Also, it is important that whether the parties of the religious right, like JI, want to address the genuine issues of the subordinate classes or only raise 'anti-elite' rhetoric for electoral victories.

There are wide research gaps in the existing literature and it's not possible to cover all aspects in a single work. That is why the researchers in this paper want to concentrate on the left-wing history 
and politics in rural areas of the KP especially elaborating on the progressive history of Malakandas absent completely in the mainstream scholarships. It is, therefore, important to understand politics on the question of land as it seemed the main space of political contestation at the peak era of left politics - the era of late 1960s and early 1970s - in rural areas. The second important aspect of this work includes the dialectic of the ruling elites and religious right at a societal level which created and reinforced the cultural hegemony of the latter. Apart from the role of the state, it is important that how various social and economic changes have played a role in shifting the pattern of politics towards the right. Socio-religious forces have been entered into both private and public spheres that have shrunk spaces for progressive politics. It is important that up to what extent those subordinated classes which were once active on progressive fronts have been side-lined from the mainstream politics and became associated with the religious right. In the end, the paper discusses that how both the politics of "common sense" and the "politics of resistance" has been claimed by the religious right, and whether, there is still a need for an organized left-wing alternative to end various sorts of exploitation or not.

\section{Methodology}

Qualitative method has been used while conducting this research work. Both primary and secondary sources are important. In primary sources, both fieldwork and archival materials have been focussed on tracing the proper history of Left politics. However, the researchers relied mostly on informal interviews and conversations as participants' observers. During fieldwork in Malakand, we took interviews from elders, political activists, intellectuals and poets of the area. Due to the limitation of written works on the left political movements and activism in the area, we relied mostly on oral history. We didn't use a questionnaire or formal interview except in a few cases. We relied to be participant observers and conducted open-ended interviews and group discussions. Also, archival materials are important to trace the history of political movements in the late 1960s' and early 1970s'. The researchers visited to National Archives and Library, Peshawar which contains important lists of the peasant-landlord conflicts and reports of special branches, police, etc. Apart from tracing the progressive history of the area, we focused on fieldwork on social, political, and economic changes taken place in the last few decades, and how it is connected to the retreat of left and the rise of the religious right. In secondary sources, we have focused on the available literature written on left politics and also on the rise and expansion of religious right in Pakistan. Moreover, we consulted thoroughly the available literature containing a sociological explanation of the recent religiopolitical movements of the religious right. In the vernacular, the researchers have studied Pashto Magazines, specifically Pakhtoon and Leekwal, and other prose and poetry books.

\section{Research Questions}

1. What are the changing global political dynamics, state policies, and various sociological changes in political development in Khyber Pakhtunkhwa Pakistan?

2. What are the left-wing and religious parties' influences at a social level in KP Pakistan?

\section{Theoretical Framework}

The main focus of this work is on the radical political shifts which have taken place in the last few decades in Pakistan with the changing global and national political scenario. The focus has been further narrowed down to the politics of a particular area, Malakand, where the left forces had been ousted from the mainstream politics and the religious right, besides influencing wider discourses and 'public opinion', have also been jumped to champion the cause of the subordinate classes on the question of class. It is difficult to frame this work by applying a fixed theory. However, Gramsci's (1971) theory of "hegemony" and "common sense" is helpful up to an extent. Apart from Gramsci, "neo-Marxist" and "Post-Marxist" scholars are important to understand politics among varying parties/groups with different ideological commitments and political programs and the role of the state in patronizing one particular ideological group over another.

Marxist and "post-Marxist" theorists have discussed the concept of hegemony that how various parties/groups engage in politics to maintain and counter-hegemony. The most influential among them, as discussed above, is the Italian philosopher and political thinker, Antonio Gramsci. Gramsci's (1971) theory of hegemony is crucial to understand the social control of one social/fundamental group over others: He discusses that how one particular class or group exercises hegemony in a society through 'moral, intellectual and political leadership'. Besides the economic hegemony, the ruling class needs moral, intellectual, and political leadership. In the context of Pakistan, it's the oligarchic elites - the military is dominant among them - with the moral and 
intellectual support of the religious right have established hegemony in the 'civil society'. According to Gramsci, hegemony is created when a fundamental group presents a reality and a world view and accepted by the subordinate classes as a "common sense". However, hegemony is never completed as various ideological groups exist in a society and do continuous struggle (Bates, 2015). New political projects emerge as a counter-hegemonic project to challenge the hegemony of the ruling elites. Gramsci further argues that for constructing hegemony the "war of position" has to be fought in the 'civil society'. In other words, consent lies within the 'civil society', while force lies in the 'political society'. In the context of Pakistan, "the religious right has become an important part of the oligarchic order since the Gen Zia regime. In theory, hegemony is created after getting the consent of the people in the civil society; however, in practice, hegemony is never created by the ruling elites only through consent, but rather through the dialectics of consent and force. In short, hegemony is the "dialectics of coercion and consent" (Gramsci, 1971).

French Structural Marxist, Althusser (1984) argued that the Church as one of the powerful ideological state apparatuses that reproduce the ideologies to enable the bourgeoisie to retain and enhance class power. The state always uses cultural institutions to establish hegemony. In the context of Pakistan, especially after the Zia regime, the ruling elites have maintained right-wing hegemony by instrumentalizing their version of religion and 'nationhood' into every sphere of life through different cultural institutions such as school curriculums, mosques, newspapers, etc.

Among the "post-Marxists" intellectuals, the work of Mouffe and Laclau (2001) is important in explaining the concept of hegemony. Both writers focus on the alternatives to hegemonic order within a liberal democratic system. They focus on the need for an agonistic approach to politics instead of an antagonistic one between opposing ideological groups in a democratic system. In the context of Pakistan, one ideological group, i.e. the left, is completely missing from the mainstream politics from the last few decades and the struggle for power is contested among various 'brands' of right-wing parties/groups. Cultural hegemony of the religious right exists at a societal level without having coherent alternative groups. The expansion of religious idioms as a common-sense language into the wider social formation has made all alternative modes of politics unacceptable. Any alternative form of politics, no matter how genuine it might be, is often looked with suspicion or a conspiracy against Pakistan. Anyhow, as discussed above, the main focus of the paper is related to a particular case study and emphasis would be given to the oral history instead of theoretical fixation.

\section{Discussion}

There is, unfortunately, no coherent work done so far exclusively on the changing political and cultural trends in Pakistan. Literature available though in pockets that help to understand the politics of left and right and its relation to the state in Pakistan. This paper has focussed extensively on the available literature written on the history of the left politics in Pakistan. Indeed, there are a few quality books and valuable Ph.D. theses that give us a broader overview of progressive politics in Pakistan. There is still little literature that has done justice to trace the complete history of the left political movements and progressive political parties in different parts of the country. As discussed above, the available literature often focussed on the left activism and social movements in the urban centers of the country such as Karachi, whereas, there is a deficiency of literature on the left politics and political movements in the rural areas especially in the smaller provinces. Besides tracing the proper history of the left in Pakistan, there is no coherent work on the religious right's attempt to cover the social bases of the left.

Modern states often rely on cultural institutions for 'legitimacy' and 'moral leadership'. In the context of Pakistan, the nexus of religion and state provides moral and intellectual legitimacy to the ruling elites. As the ideas and discourses of the religious right are more congruent to the 'state ideology' and 'official nationalism', that's why the ruling elites needed their ideological and moral support to resolve the identity crises and to maintain legitimacy(Toor, 2011). In other words, the hegemonic ideological position of the religious right at a societal level is the result of a dialectic between the 'state ideology' and right-wing socio-political forces - as both reinforce each other. Apart from the state's patronization of 'Islam', the changing socio-political conditions were also conducive to the Religious Right, and largely helped them to expand their roots at a wider societal level. As Akhtar (2018) argues that religious idioms dominate society at the very grass root level in Pakistan.

The case of Malakand is worth noticing where radical shifts have been taken place towards the right in the last few decades. Most of the people came to know about the region after the rise of 
Sufi Muhammad and with the arrival of the Taliban. These changing trends are not as simple as it appears to be: for instance, on one side subordinate classes have been widely influenced by the discourses and practices of the religious right, but on the other side, the religious parties are still unsuccessful to translate the growing religiosity into electoral victories (Ziar, 2016). For instance, Malakand is still not dominated electorally by political parties of the religious right; Pakistan Peoples' Party (PPP) and Pakistan Tehrik-i- Insaf (PTI) are the dominant political forces in the district, notwithstanding religious forces have gained some ground in the last two decades. However, the existing politics of PPP or PTI is not based on any broad-based progressive program for the downtrodden sections of society. Almost all mainstream political parties, class, gender, and national questions are not the mobilizing factors; rather patronization, localization, and opportunism are the dominant trends of electoral politics in the area-which is almost the case in other parts of the country ( Jan, 2010). There is also an absence of coherent discussion against the religious right's growing orthodoxy and the state's repressive role at the societal level among the mainstream parties. It, thus, manifests that electoral politics is not the only standard to gauge the dominant prevailing ideas in any society.

Pakistani ruling elites from its inception remained exclusive to accept diversity and dissenting voices. The state not only rejected the alternative views of state nationalism presented by various ethno-nationalists and leftists, but had always adopted undemocratic steps to eliminate them from the mainstream political arena (Ahmed, 1999). Apart from the role of the ruling elites, religious parties' developing sociological roots among the subordinate classes have given them further impetus (Malik, 2016). Similarly, the increasing role of socio-religious groups at a societal level is very important in shaping the world view of the subordinated classes.

There are plenty of reasons for the decline of left and rise of right-wing forces in Pakistan; for instance, the retreat of left-wing forces in international politics, impacts of regional geopolitics and neo-liberalism, and the systematic support of Pakistani state to the right-wing socio-political forces to diffuse left/progressive politics. Pakistani state had been supported religious parties/groups in the province of Khyber Pakhtunkhwa (then NWFP) and Federally Administered Tribal Areas (FATA) to achieve multiple purposes; countering Pakhtun nationalism in Pakistan; containing communism or Russia under the patronage of the US; diffusing progressive politics in Pakistan and maintaining the legitimacy of the ruling elites using the notion of 'Islam'. In other words, the Pakistani state - with the support of the US and Arab countries - systematically provided space to the right-wing socio-political forces to undermine progressive and dissenting voices (Toor, 2011).

To deconstruct general perception about the people of Malakand, it is important to know the history of left and rise and expansion of religious rights due to multiple reasons in a proper sequence. First, it is crucial to trace the proper history of left politics-as it seems absent in most of the scholarships being conducted on places like Malakand. It includes the history of the left-wing political movements and political parties in Pakistan, especially in the KP (the then NWFP) province. The role and ideology of the state is important to understand nature of left-wing politics in Pakistan: Due to exclusive 'official nationalism' of the ruling elites based on 'Islam and Urdu', progressive version of an alternative nationalism based on accepting cultural diversity were rejected ( Ahmed, 1999). National Awami Party (NAP) remained one of the successful experiments between the ethnonationalists and the left (Ali, 2015).

Progressive political history of places such as Malakand or Swat is absent in the mainstream academia. It is important to trace the progressive history of Malakand as the place is being affiliated recently only with religious extremism. In the late 1960s and early 1970s, Malakand was a hub of progressive political movements: The same place had experienced indigenous movements of the landless immigrants against the landed khans who were patronized by the state in the guise of Riwaj. Similarly, like in many other parts of the province, peasant uprising also took place in different parts of Malakand against the landed khans. Besides the experience of indigenous Awami Khel movement and peasant uprisings, Malakand remained a hub of 'progressive' Pashto poets. It has given birth to some remarkable poets, whose poetry is an inspiration for progressive and nationalist Pukhtuns on both sides of the Durand line. However, the rise, deepening, and penetration of the religious right into the wider societal level have erased that chapter of society from the minds of common people.

Secondly, this work focuses on the rise of the religious right and its changing ideological tactics to gain support of those subordinated classes which were once represented by the left. After 
the retreat of the left, religious right tried to capture those empty spaces that were once represented by them (Iqtidar, 2010). For instance, the religious right had never showed interest to address the questions of class in the past but recently made different peasant and labor organizations. In addition to it, 'new' social classes have emerged in the last few decades that are more exposed to the ideas of the religious right. Most importantly, the religious right raised the question of class on many occasions in the last two decades for making their religiopolitical movements popular (Jan, 2010). For instance, Sufi Mohammad raised the rhetoric of poor and rich to garner wider support of the former in his movement. Although, it is another matter that up to what extent the religious right remained successful in addressing the question of class and working people. It is a matter of serious concern that despite undemocratic policies of the ruling elites and violence of religious right, an alternative form of organized politics for peace, tolerance, and equality is still absent in the mainstream.

\section{References}

Ahmed, A. (2005). Frontier Gandhi: Reflections on Muslim nationalism in India. Social Scientist 33, $(1 / 2): 22-39$.

Ahmed, A. S. (1986). Pakistan Society: Islam, Ethnicity, and Leadership in South Asia. Karachi: Oxford University Press.

Ahmed, E. (2004). Roots of the Religious Right. In Between Past and Future: Selected Essays on South Asia, edited by D. Ahmed, I. Ahmed, Z. Ahmed and Z. Mian. Karachi: Oxford University Press.

Ahmad, I. (2010). The Rise and fall of the Maoist Movement in Pakistan. Institute of South Asian Studies, 102.

Ahmed, F. (1999). Ethnicity and Politics in Pakistan. Karachi: Oxford University Press.

Akhtar, A. S. (2018). The politics of "common sense" in Pakistan. Cambridge: Cambridge University Press.

Alavi, H. (1972). The State in Post-Colonial Societies: Pakistan and Bangladesh. New Left Review 74: 59-81.

Ali, K.A. (2011). Communists in a Muslim Land: Cultural Debates in Pakistan's Early Years. Modern Asian Studies 45, (3): 501-534.

Islah, S (2015). Surkh Salam: Communist politics and class activism in Pakistan, 1947-1971. Karachi: Oxford University Press.

Althusser, L. (1984). Essays on Ideology. London: Verso.

Asad, T. (1972). Market Model, Class Structure, and Consent: A Reconsideration of Swat Political Organisation. Man, New Series, 7, (1): 74-94.

Bangash, A. (1972). Afzal Bangash Speaks: Class Struggle and Not Tribal War. Pakistan Forum, 2 (9/10), 14-18.

Barth, F. (1959b). Political Leadership Among Swat Pathan. London: The Athlone Press.

Bates, T. R. (1975). Gramsci and the theory of Hegemony. Journal of the history of ideas, 36, (2): 351-367.

Gramsci, A. (1971). Selections from the Prison Notebooks. London: Lawrence \& Wishart.

Haqqani, H. (2005). Pakistan: Between Mosque and Military. Washington: Carnegie Endowment for international peace.

Haroon, S. (2007). Frontier of Faith: Islam in the Indo Afghan Borderland. London: C. Hurst and Co.

Hayat, M. (2009). Still 'Taming the Turbulent Frontier'? The State in Federally Administered Tribal Areas of Pakistan. JASO-online N.S.I, (2): 179-206.

Iqtidar, H. (2010). Jama'at-e-Islami of Pakistan: Learning from the Left. In Beyond crises: Reevaluating Pakistan, edited by Naveeda Khan. New Delhi: Routledge.

Jan, M. A. (2010). Contested and Contextual Identities: Ethnicity, Religion, and Identity among the Pakhtuns of Malakand, Pakistan. Toronto: York University.

Laclau, E \& Chantal, M .(2001). Towards a radical democratic imaginary. In Radical democracy and collective movements today, edited by A. Kioupkiolis and G. Katsambekis.

Leghari, I. (1979). The Socialist Movement in Pakistan: An Historical Survey, 1940-1974. Montreal: Laval University.

Lindholm, C. (1982). Generosity and Jealousy: The Swat Pukhtuns of Northern Pakistan. New York: Columbia University Press. 
Malik, J. (2016). Islamization in Pakistan (1977- 1985): The Ulema and their places of learning. Islamic Studies 28, (1): 5-28.

Mamdani, M. (2005).Good Muslim, Bad Muslim: America, the Cold War, and the Roots of Terror. Lahore: Vanguard Books.

Nasr, S. V. R. (1994). The Vanguard of Islamic Revolution: The Jamaat-i Islami of Pakistan. London: I.B. Tauris.

Rome, S. (2013). The North-West Frontier (Khyber Pakhtunkhwa): Essays on History. Karachi: Oxford University Press.

Sail,S. (2012). Da Veer pa Cham ki Waar da Naghmo de. Malakand: Pukhto Adabi Jarga Malakand.

Shah, M (2002). Social forces and ideology in the making of Pakistan. Economic and Political Weekly 37, (51): 5119-5124.

Swat, P (2010). Islam as Ideology of Tradition and Change: The "New Jihad" in Swat, Northern Pakistan. Comparative studies of South Asia, Africa and the Middle East 30, (3): 595-609.

Toor, S. (2011). The state of Islam: Culture and Cold war politics in Pakistan. London: Pluto Press. 